\section{Observation of a Whale Shark Rhincodon typus (Orectolobiformes: Rhincodontidae) in the offshore waters of Rushikulya, Orissa, India}

\author{
Sajan John \\ Wildlife Institute of India, PB\#18, Chandrabani, Deharadun, \\ Uttarakhand 248001, India \\ Email: johns@wii.gov.in, sajanjohn09@gmail.com
}

The Whale Shark Rhincodon typus Smith, 1828 grows to a length of approximately $12 \mathrm{~m}$ and a weight of approximately 30 ton making it not only the largest fish but also one of the largest extant animals. Despite its size, wide-ranging distribution and the ease with which it is identified, Whale Shark sightings are infrequently reported. The rarity of Whale Shark sightings has thus resulted in global concern regarding the health of whale shark populations. This concern led to the species being assigned Vulnerable status by the IUCN Red List of Threatened Species (Norman 2005). Additionally, Whale Sharks are protected in India under Schedule-I of the Indian Wildlife (Protection) Act - 1972 (IWPA 2003).

On 22 February 2009, a Whale Shark, accompanied by two sucker fish (Remora sp.) was sighted at $1120 \mathrm{hr}$ (IST), $3 \mathrm{~km}$ offshore and $12 \mathrm{~km}$ north of the Rushikulya River mouth (85'10'18.26N \& 19²6'28.45E). Bottom depths at the sighting location ranged from $18-20 \mathrm{~m}$; however, the shark was primarily observed at the surface (Images 1 \&

Date of publication (online): 26 May 2010

Date of publication (print): 26 May 2010

ISSN 0974-7907 (online) | 0974-7893 (print)

Editor: Sanjay Molur

Manuscript details:

Ms \# 02245

Received 26 June 2009

Final received 25 March 2010

Finally accepted 08 April 2010

Citation: John, S. (2010). Observation of a Whale Shark Rhincodon typus (Orectolobiformes: Rhincodontidae) in the offshore waters of Rushikulya, Orissa, India. Journal of Threatened Taxa 2(5): 896-897.

Copyright: (c) Sajan John 2010. Creative Commons Attribution 3.0 Unported License. JoTT allows unrestricted use of this article in any medium for non-profit purposes, reproduction and distribution by providing adequate credit to the authors and the source of publication.

Acknowledgement: Thanks to WII-DGH Sea turtle telemetry project for the logistics, Adhith Swaminathan for providing the photographs, William Driggers (NOAA) for reviewing the manuscript, Suresh Kumar (WII), B.M. Praveen Kumar (WTI) for suggestions, C.E. John (NBFGR/CMFRI), P.M. Vipin (CIFT) for providing the references and my field assistants at Rushikulya, Orissa.

\section{OPEN ACCESS I FREE DOWNLOAD (C) (i) @}

2). The atmospheric and sea surface temperatures at the sighting location were $31^{\circ} \mathrm{C}$ and $29^{\circ} \mathrm{C}$ respectively; salinity was $34 \%$. The length of the whale shark was between $4.5-5$

$\mathrm{m}$ based on its size relative to the $7 \mathrm{~m}$ boat from which the observation was made. As the length at maturity for Whale Sharks is reported to be above 9m (Colman 1997), the shark we observed was likely a juvenile. Interestingly, most Whale Sharks reported globally range from 4-10 $m$ in length (Colman 1997) and in Indian waters, $25 \%$ of the recorded whale sharks are between 5-6 $\mathrm{m}$ in length (Pravin 2000).

Sightings of Whale Sharks have been reported from almost all maritime states of India including Gujarat (Hanfee 2001), Maharashtra (Jadhav et al. 2005), Karnataka (Kemparaju et al. 2002), Kerala (Paul 2006), Tamil Nadu (Rajapackiam et al. 2006), Andhra Pradesh (Rao 1992), West Bengal and Goa (Pravin 2000; Choudhary 2008). Recently, there has been an increase in Whale Shark sightings off the Orissa coast, such as those documented by Bar (1998) and Rao (2004). Additionally, On March 2008, fishermen of Purnabandha Village (village near Rushikulya River mouth) reported a Whale Shark approximately $4 \mathrm{~km}$ offshore near Rushikulya River mouth (Suresh Kumar, WII pers. comm. 27 February 2009). Furthermore, the Orissa Diary (Anonymous 2009a) reported the stranding of a dead, $5.5 \mathrm{~m}$ Whale Shark at Gopalpur (a coastal town, $25 \mathrm{~km}$ south of Rushikulya) in February 2009 and The Hindu (Anonymous 2009b) reported about beaching of another Whale Shark at Gopalpur on November 2008. Whether or not the increase in observations of Whale Sharks from the region reflects an increase in the abundance of the species or a result from increased public interest in the species is unknown. However, it is evident that Whale Sharks inhabit the Orissa coast with an unknown periodicity.

\section{REFERENCES}

Anonymous (2009a). Dead whale shark recovered from Gopalpur beach. Orissa diary. <http://www.orissadiary. com/Shownews.asp? $i d=10541>$. On line version dated 03 February 2009.

Anonymous (2009b). Whale shark washed ashore. The Hindu. <http://www.hindu.com/2009/02/03/stories/ 2009020351020300.htm> 03 February 2009.

Bar, S. (1998). On a whale shark landed at Paradeep, Orissa. Marine Fisheries Information Service, Technical and Extension Series 155: p 20

Choudhary, R.G., A. Mookerjee, V. Menon \& D. Joshi (2008). Turning the Tide - The Story of A Campaign to Save Vhali, The Whale Shark in Gujarat. Wildlife Trust of India, New Delhi, 14pp.

Colman, J.G. (1997). A review of the biology and ecology of the whale shark. Journal of Fish Biology 51: 1219-1234 


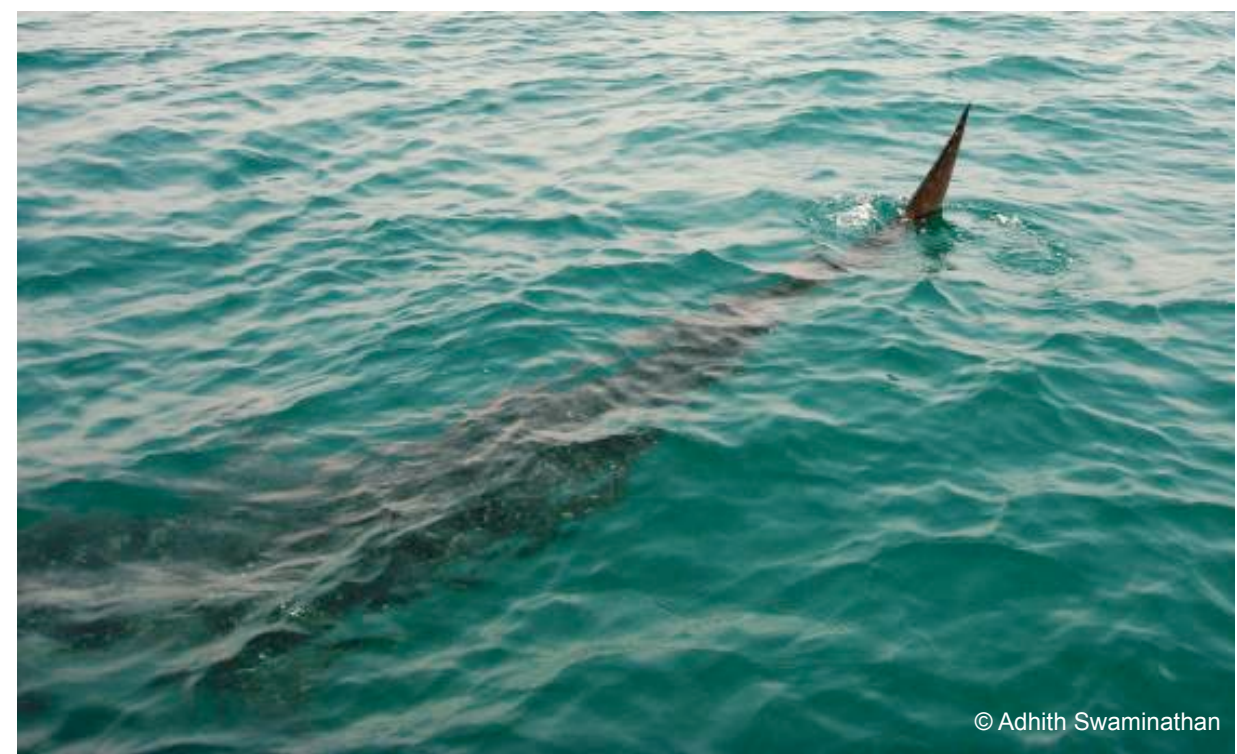

Image 1. Whale Shark, with its caudal fin out of the water north of Rushikulya River mouth on 22 February 2009

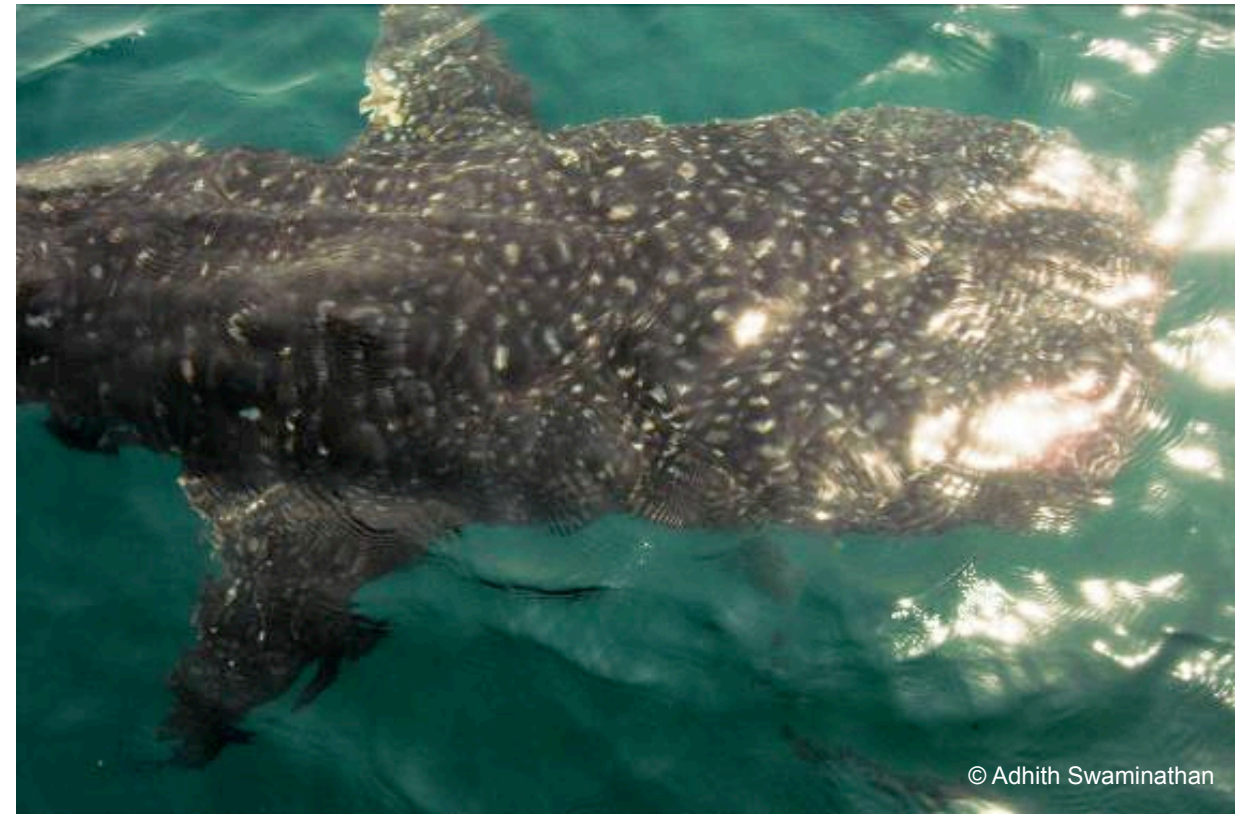

Image 2. Whale Shark on the water surface north of Rushikulya River mouth on 22 February 2009

Hanfee, F. (2001). Trade in Whale shark and its products in the coastal state of Gujarat, India. Report to the Rufford Foundation. TRAFFIC India.

Jadhav, D.G., B.B. Chavan, A.D. Sawant \& S. Sundaram (2005). On a Whale Shark, Rhiniodon typus landed at Versova, Mumbai. Marine Fisheries Information Service, Technical and Extension Series 18(186): 18.

Kemparaju, S., L. Muniyappa \& H.S. Mahadevaswamy (2002). on a Whale Shark Rhiniodon typus landed at Malpe, Udupi district, Karnataka. Marine Fisheries Information Service, Technical and Extension Series 171: 9.

Norman, B. (2005). Rhincodon typus. In: IUCN 2010. IUCN Red List of Threatened Species. Version 2010.1. <www. iucnredlist.org>. Downloaded on 16 April 2010.

Paul, S. (2006). Whale Shark Rhiniodon typus landed at Kollam. Marine Fisheries Information Service, Technical and Extension Series 190: 22.
Pravin, P. (2000). Whale Shark in the Indian Coast - Need for Conservation. Current Science 79(3): 310-315.

Rajapackiam, K. \& S. Mohan (2006). A giant Whale Shark (Rhincodon typus) caught at Chennai fisheries harbour. Marine Fisheries Information Service, Technical and Extension Series 189: 25.

Rao, C.V.S. (1992). The occurrence of Whale Shark Rhiniodon typus along the Kakinada coast. Marine Fisheries Information Service, Technical and Extension Series 116: 19.

Rao, S.V.S. (2004). Landing of Whale Shark, Rhiniodon typus at Gopalpur Ganjam District, Orissa. Marine Fisheries Information Service, Technical and Extension Series 181: 14.

IWPA (2003). The Wildlife (Protection) Act, 1972. Wildlife Trust of India \& Natraj Publishers, Dehradun, India, 149-163pp. 